\title{
The 2004 User Survey at the University of Hong Kong Libraries
}

\author{
Helen Woo
}

An online user survey, with the option to complete in the print format, was conducted between February 9 and February 22, 2004. The aim of the survey was for users to evaluate the performance of the main library and the six branch libraries, to identify any performance gaps, and to find out user preferences for print and electronic materials. A total of 2,564 returns were received. The results showed that 68.8 percent of the respondents prefer to use journals online compared to 31.2 percent who prefer to use print journals; and 71.8 percent of the respondents prefer to use printed books compared to 28.2 percent who prefer to use electronic books. Eighty-eight pages of written comments were received covering a wide array of issues.

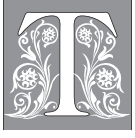

he University of Hong Kong (HKU), founded in 1911, is the first tertiary institution in Hong Kong. It has more than 20,300 students $(11,700$ undergraduates and 8,600 graduates) and 2,250 academic staff. The University of Hong Kong Libraries, founded in 1912, has six branch libraries: Fung Ping Shan Library (1932), Yu Chun Keung Medical Library (1965), Lui Che Woo Law Library (1969), Education Library (1978), Dental Library (1981), and Music Library (1981). Total collections include 2.3 million volumes, 1.5 million reels/pieces of microform, 70,000 audiovisual items as of May 2004 and 25,200 electronic journals, 143,792 electronic books, and 517 databases as of June 2004.

User surveys have been administered on a regular basis since 1995 to measure user satisfaction, to understand user needs with a view to strengthening the depth and breadth of the library collections, and to make improvements in the libraries' facilities, services, and staff. A User Survey Task Force composed of four members from a cross section of the University of Hong Kong Libraries was created in October, 2003, to conduct the current librarywide user survey from February 9 to February 22, 2004..$^{1}$ Administration of the survey was subsequently incorporated into Operational Priorities 4, (2003-2004) Strategic Direction 6 of the Libraries' Strategic Plan for 2003-2006 to communicate more effectively internally and externally with the university, Hong Kong, Asian, and international communities in January $2004 .^{2}$

\section{Purpose of the 2004 User Survey}

The 2004 user survey was conducted to:

Helen Woo is an Assistant Librarian at the University of Hong Kong Libraries and Chairperson of the 2004 User Survey Task Force; e-mail: hmlam@hkucc.hku.hk. 
- provide an opportunity for users to evaluate our performance;

- identify performance gaps and make improvements in the problem areas with large gaps;

- identify information needs, services, and library resources that are most and least important to users;

- study user preferences for print and electronic materials;

- study different information needs of users from different library locations;

- study different information needs from different patron types;

- use the collected data as a management tool for strategic planning.

\section{User Survey Design and Methodology}

A literature review was conducted prior to calling the second meeting as well as throughout the design and implementation stage. ${ }^{3-23}$ Surveys from a number of libraries, including The University of Newcastle, Australia; the University of California at San Diego; and Rochester Institute of Technology, to name a few, were consulted in order to obtain ideas on attributes to be included and ways to set the questions.

The 2001 main library user survey was reviewed item by item to make decisions on what questions to retain and delete with the goals of the 2004 user survey in mind. A set of brief and clear instructions on how to complete the questionnaire was given at the beginning of the questionnaire, and participants were informed that their responses would be kept confidential. Anonymity permits respondents to be more candid. An intensity-scaled choice of 1 to 5 rating items, where 1 is low, 3 is moderate, and 5 is high, and openended items that offer respondents the opportunity to give comments and suggestions was used.
The initial draft questionnaire included five categories: (1) service quality; (2) facilities, equipment, and physical environment; (3) resources; (4) electronic resources; and (5) new services implemented by HKU Libraries since 2001.

The focus of the user survey was twofold: first, to identify performance gaps (respondents were asked to assess the importance-and the library's performance - of each attribute in order to identify problem areas with large gaps that could be targeted for improvement); and second, to monitor the library's migration from print to electronic resources. ${ }^{24}$

Demographic questions that could be answered easily were placed at the end of the questionnaire.

The master questionnaire for the main library then was sent to the six branch librarians to make amendments to reflect their libraries' unique resources and services.

Implementation of a Web survey is much more technically involved than that of a print survey. Twenty man-days were spent in the creation of the seven Web surveys. ${ }^{25}$ There are many issues related to the technical control that the survey designer needs to address. The work flow has to be revised with each change made to the questionnaire. The coding for each of the seven Web surveys varies according to each library's unique resources and services. Furthermore, all identical questions have to be mapped for comparison purposes, making the checking criteria quite complicated. Considerable time was spent on improving the outlook of the Web surveys also. Respondents initially were required to answer all the questions to avoid missing data before they could successfully submit the user survey. However, it was found that they had to scroll the screen between error messages and questions with the missing answers, which proved to be very tedious. To minimize "abandonment" affecting the 
return rate, the User Survey Task Force made the decision to drop forced-choice questions. An e-mail account was created to offer respondents the option of sending inquiries to the task force chairperson.

\section{Pilot Tests}

Two pilot tests were conducted to improve reliability and validity. The first was conducted on November 11, 2003, to assess the adequacy of the instructions, the clarity of the format, and whether the time needed to complete the survey was reasonable. Revisions to the user survey were made based on an interview with the pilot respondents.

A second pilot test was conducted on November 21, 2003, and further revisions were made.

\section{User Survey Amendments}

To make the length of the user survey more manageable and in the hope of obtaining a higher return, two sections, “Facilities, Equipment \& Physical Environment" and "New Services Implemented by the University of Hong Kong Libraries since 2001," were removed. ${ }^{26}$ As a result, the time it took to complete the user survey was reduced by five minutes, from fifteen to twenty minutes to ten to fifteen minutes.

The dimensions of the 2004 user survey evolved with each iteration becoming more refined and focused. Fine-tuning was completed on November 24, 2003, after twenty-three iterations. ${ }^{27}$

The draft multi-issue questionnaire was submitted to the libraries' Quality Assurance Team for its review and was endorsed with minor revisions. ${ }^{28}$ (See figure 1.)

\section{Sampling Technique}

The method adopted for choosing the sample was the nonprobabilistic by convenience. Respondents were drawn from those who were available and willing. As a result, the task force was limited to making inferences to the broader population from those who returned the user surveys. Therefore, it must be stressed that their representativeness in relation to the population could not be completely ascertained.

\section{Data Collection Technique}

Patrons had the option of completing one of the seven questionnaires anonymously in the online or print format. Print copies were available for distribution at the reference/circulation counter at the main library and branch libraries. However, effort was expended in encouraging responses via the Web and the conventional mode was used only when necessary. Library staff assisted in data entry for all the print returns, and data from the online returns were captured electronically. The computer program treated missing answers as N/A (not applicable), and they were not used to calculate any statistics.

\section{Promotional Methods}

To encourage a higher return rate, the following promotional methods were adopted:

- distribute flyers to users at all libraries;

- affix posters at the entrances of all libraries;

- install pop-ups on the screen savers of all public computers, including those at the Knowledge Navigation Centre in the main library;

- publish announcements on the plasma TVs at the main library and at those branch libraries with plasma TVs;

- publish a bulk-mail announcement at the HKU intranet at the commencement of the user survey, followed by two follow-up announcements;

- display a pop-up of the user survey the first time the libraries' home page is logged on by each user; 


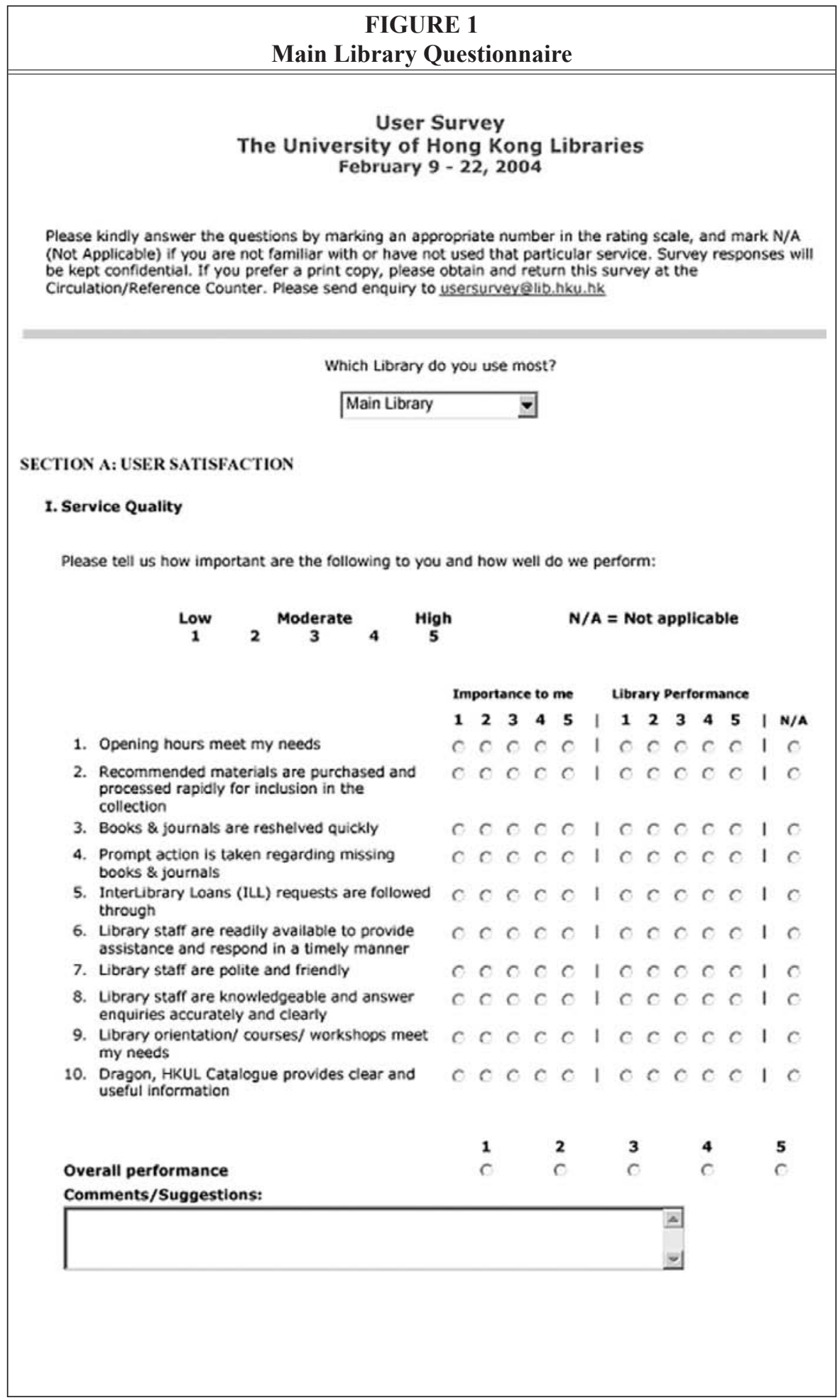




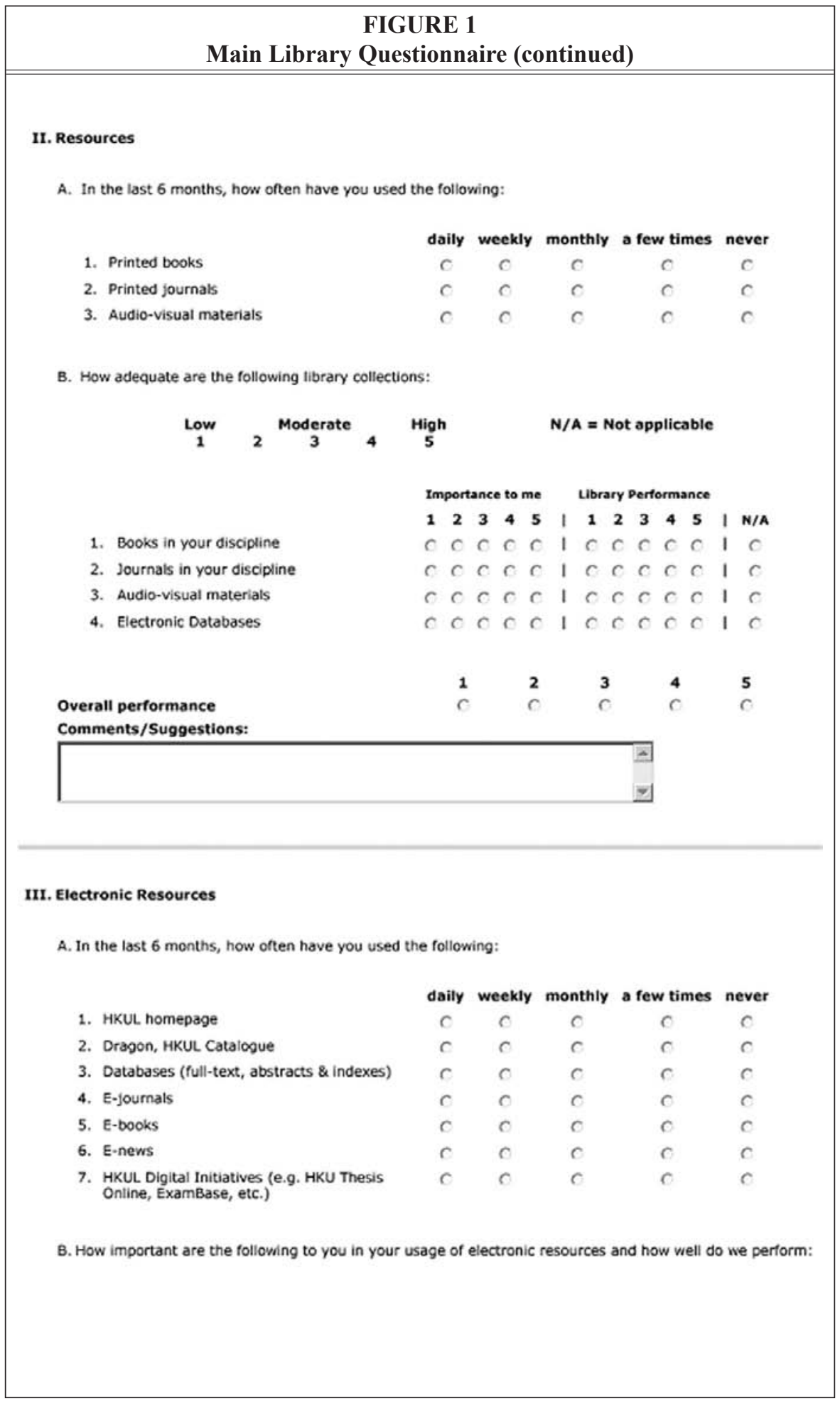




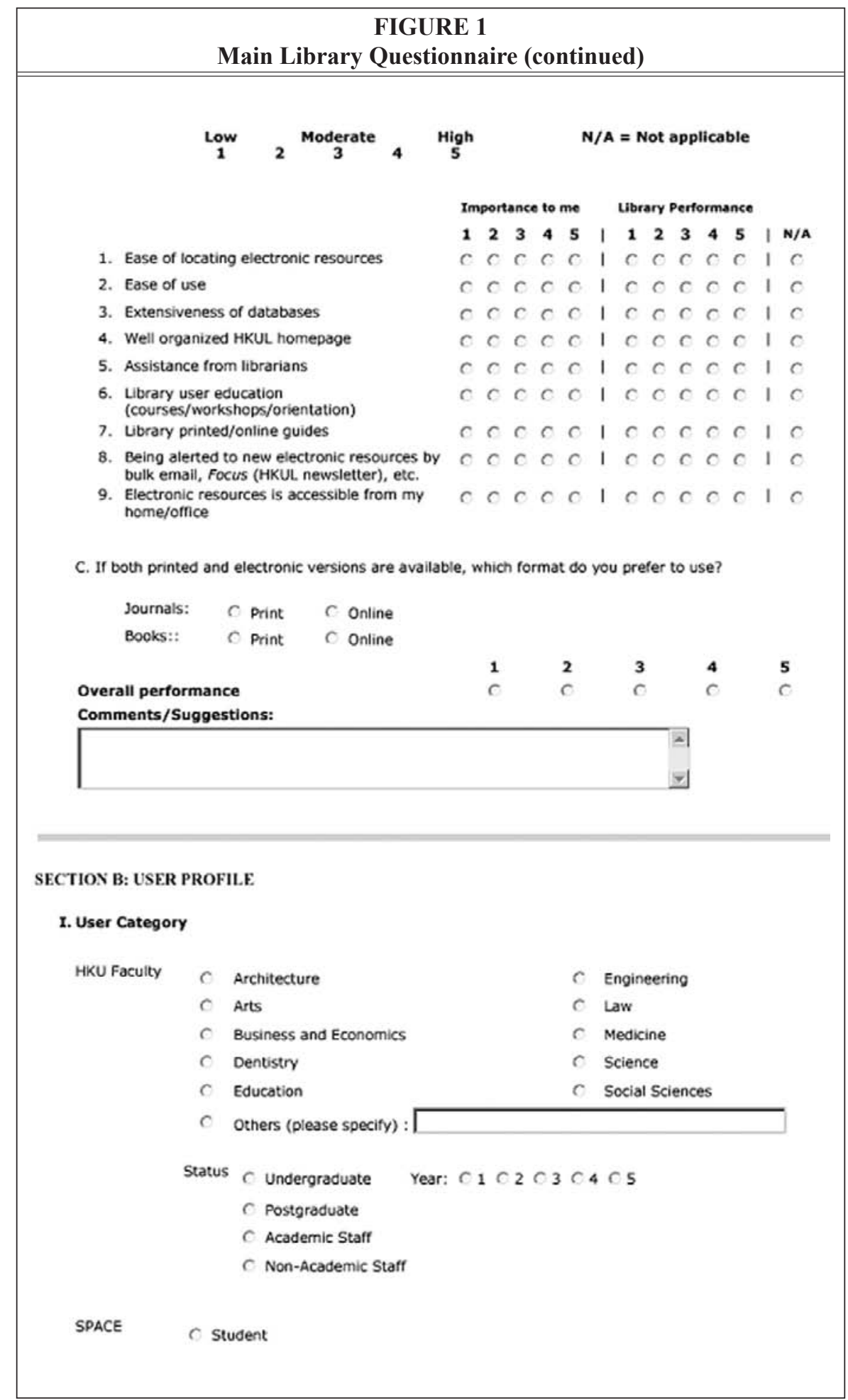




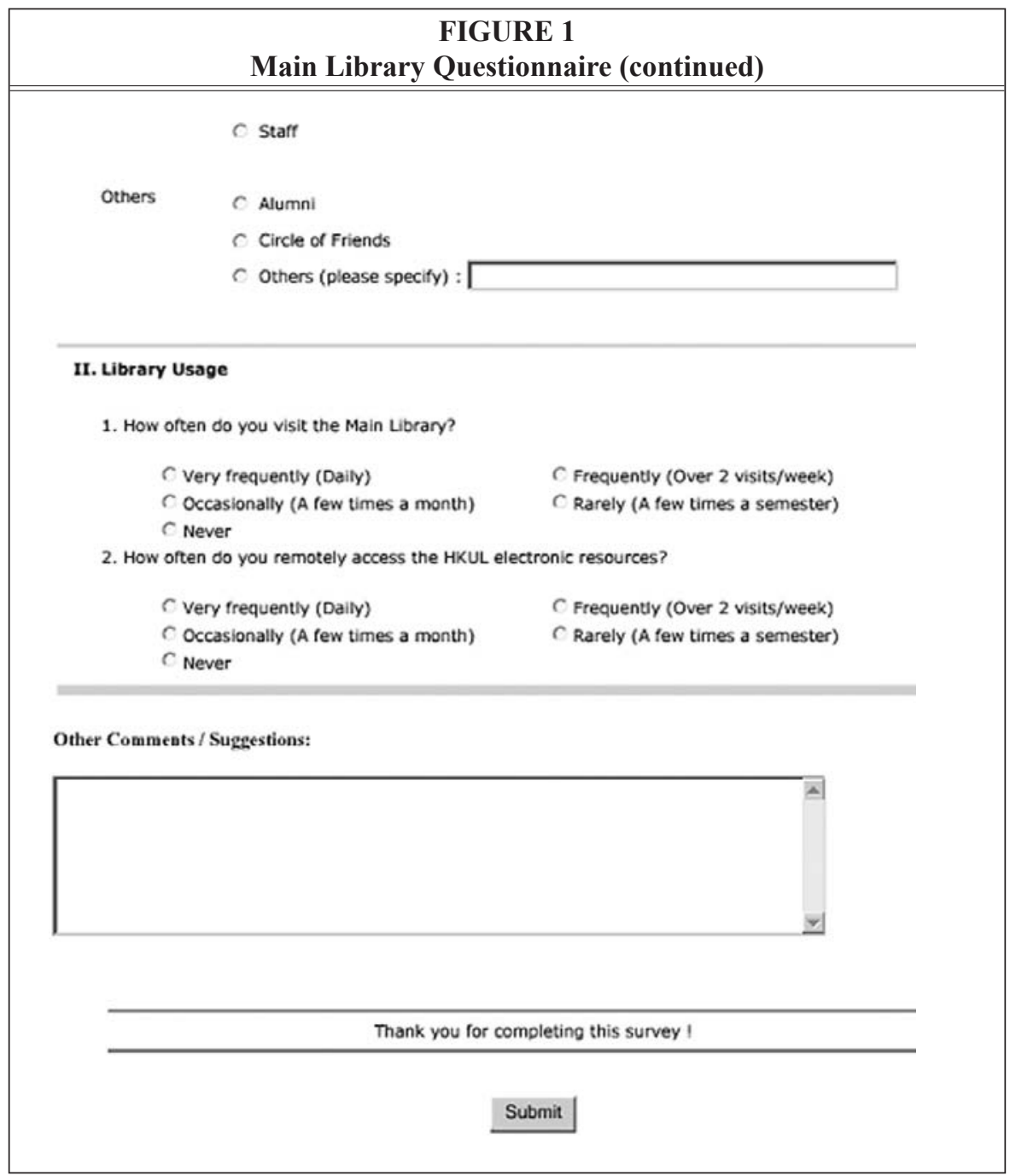

- award a souvenir notepad, compliment of a database vendor, as an incentive to every user who has completed the survey successfully;

- mount an announcement about the user survey with a direct link to the Web survey on the "Spotlight Section" of the libraries' home page;

- affix user survey flyers on the monitors of each public monitor to alert users;

- display the souvenir notepad and flyer on service counters to draw the attention of users.

\section{User Survey Results}

Results from the data captured electronically were compiled. Tables and figures from the ratings assigned by respondents were generated. ${ }^{29} \mathrm{~A}$ total of 2,564 returns were received, and the main library accounted for almost twothirds $(61.6 \%)$ of the total return. (See table 1.)

The Music Library received relatively few returns in the first week. It was speculated that the few returns were possibly due to the way the first question was 
framed (Which library do you use most?). The Department of Music has relatively few music major students, but many part-time students taking one course in music. The latter students probably designated the main library as the library they frequented most and completed the main library survey. Music Library users therefore were invited to complete a print survey commencing the second week, and the number of returns was then much improved.

\section{User Survey Returns by Faculty}

The students and staff of HKU's School of Professional and Continuing Education (HKU SPACE) accounted for one-quarter $(25.6 \%)$ of the total returns, alumni for 12.9 percent, and the Faculty of Arts for 10.1 percent. (See table 2.)

\section{User Survey Returns by Patron Type}

Undergraduates accounted for one-third $(33.5 \%)$ of the total returns, HKU SPACE students for almost one-quarter (23.1\%), and postgraduates for 15.7 percent. (See table 3.)

\section{Composite Results}

Scores for each of the thirty attributes from all 2,564 respondents were compiled and tabulated.

\section{Ranked Performance versus Importance}

Table 4 shows the relationship between the libraries' performance in each of the thirty attributes ranked from 1 to 30 with their corresponding importance ranking. The greater the difference between the two translates into more significant gaps. The three highest performance areas are (1) library staff are polite and friendly (4.06 out of 5 , or $81.2 \%)$, (2) library staff are readily available to provide assistance and respond in a timely manner (4.04), and (3) Dragon, HKU Libraries catalogue, provides clear and useful information (3.99). The three lowest performance areas are (1) prompt action is taken regarding missing books and journals (3.31 out of 5 , or $66.2 \%)$, (2) scores (3.33), and (3) audiovisual materials (3.37), a range of 15 percent between the top- and bottommost performance ranking.

\section{Ranked Importance versus Performance}

Table 5 demonstrates the relationship between respondents' perceived importance in each of the thirty attributes ranked from 1 to 30 with their corresponding performance ranking. The greater the difference between the two translates into more significant gaps. The three most important areas are (1) books in your discipline (4.55 out of 5, or 91\%), (2) Dragon,

\begin{tabular}{|l|r|r|r|r|c|}
\hline \multicolumn{7}{|c|}{ TABLE 1 } \\
\hline \hline Name of Library & Print & Online & Total & Percentage & $\begin{array}{c}\text { Souvenirs } \\
\text { Distributed }\end{array}$ \\
\hline Main library & 3 & 1,579 & 1,582 & 61.6 & 152 \\
\hline Medical library & 0 & 327 & 327 & 12.8 & 91 \\
\hline Education library & 0 & 207 & 207 & 8.1 & 178 \\
\hline Law library & 10 & 181 & 191 & 7.4 & 127 \\
\hline Music library & 67 & 66 & 133 & 5.2 & 129 \\
\hline Dental library & 0 & 89 & 89 & 3.5 & 29 \\
\hline Fung Ping Shan Library & 1 & 34 & 35 & 1.4 & With Main Library \\
\hline Total & 81 & 2,483 & 2,564 & 100.00 & 706 \\
\hline
\end{tabular}




\begin{tabular}{|l|c|c|c|c|}
\hline \multicolumn{5}{|c|}{ TABLE 2 } \\
\hline & User Survey Returns by Faculty \\
\hline \hline Faculty & Frequency & Percent & $\begin{array}{c}\text { Valid } \\
\text { Percent }\end{array}$ & $\begin{array}{c}\text { Cumulative } \\
\text { Percent }\end{array}$ \\
\hline HKU SPACE & 657 & 25.6 & 25.6 & 25.6 \\
\hline Alumni & 330 & 12.9 & 12.9 & 38.5 \\
\hline Arts & 259 & 10.1 & 10.1 & 48.6 \\
\hline Medicine & 246 & 9.6 & 9.6 & 58.2 \\
\hline Science & 193 & 7.5 & 7.5 & 65.7 \\
\hline Social Sciences & 170 & 6.6 & 6.6 & 72.3 \\
\hline Engineering & 148 & 5.8 & 5.8 & 78.1 \\
\hline Education & 138 & 5.4 & 5.4 & 83.5 \\
\hline Law & 112 & 4.4 & 4.4 & 87.9 \\
\hline Business and Economics & 84 & 3.3 & 3.3 & 91.2 \\
\hline Circle of Friends \& others & 83 & 3.2 & 3.2 & 94.4 \\
\hline Architecture & 72 & 2.8 & 2.8 & 97.2 \\
\hline Others & 44 & 1.7 & 1.7 & 98.9 \\
\hline Dentistry & 28 & 1.1 & 1.1 & 100.0 \\
\hline Total & 2,564 & 100.0 & 100.0 & \\
\hline
\end{tabular}

HKU Libraries' catalogue, provides clear and useful information (4.54), and (3) electronic resources are accessible from my home/office (4.49). The three least important areas are (1) library user education ( 3.34 out of 5 , or $66.8 \%)$, (2) library orientation/courses/workshops meet my needs (3.40), and (3) audiovisual materials (3.42), a range of 24.2 percent between the most and least important ranking.

\section{Ranked Gap Analysis}

The gap analysis survey provided insights into the gap between the im-

\begin{tabular}{|l|c|c|c|c|}
\hline \multicolumn{5}{|c|}{ TABLE 3 } \\
2004 User Survey Returns by Patron Type \\
\hline \hline Patron Type & Frequency & Percent & $\begin{array}{c}\text { Valid } \\
\text { Percent }\end{array}$ & $\begin{array}{c}\text { Cumulative } \\
\text { Percent }\end{array}$ \\
\hline Undergraduate & 859 & 33.5 & 33.5 & 33.5 \\
\hline HKU SPACE student & 593 & 23.1 & 23.1 & 65.6 \\
\hline Postgraduate & 404 & 15.7 & 15.7 & 72.3 \\
\hline Alumni & 330 & 12.9 & 12.9 & 85.2 \\
\hline Academic Staff & 145 & 5.7 & 5.7 & 90.9 \\
\hline Nonacademic Staff & 86 & 3.4 & 3.4 & 94.3 \\
\hline Circle of Friends \& others & 83 & 3.2 & 3.2 & 97.5 \\
\hline HKU SPACE Staff & 64 & 2.5 & 2.5 & 100.0 \\
\hline Total & 2,564 & 100.0 & 100.0 & \\
\hline
\end{tabular}




\begin{tabular}{|c|c|c|c|c|}
\hline \multicolumn{5}{|c|}{$\begin{array}{c}\text { TABLE } 4 \\
\text { Ranked Performance versus Importance }\end{array}$} \\
\hline Question & $\begin{array}{c}\text { Mean } \\
\text { Performance }\end{array}$ & $\begin{array}{c}\text { Rank } \\
\mathbf{P}\end{array}$ & $\begin{array}{c}\text { Mean } \\
\text { Importance }\end{array}$ & $\begin{array}{c}\text { Rank } \\
\text { I }\end{array}$ \\
\hline 1. Library staff are polite and friendly & 4.06 & 1 & 4.14 & 15 \\
\hline $\begin{array}{l}\text { 2. Library staff are readily available to } \\
\text { provide assistance and respond in a timely } \\
\text { manner }\end{array}$ & 4.04 & 2 & 4.24 & 9 \\
\hline $\begin{array}{l}\text { 3. Dragon, HKUL catalogue, provides } \\
\text { clear and useful information }\end{array}$ & 3.9901 & 3 & 4.54 & 2 \\
\hline $\begin{array}{l}\text { 4. Library staff are knowledgeable and } \\
\text { answer inquiries accurately and clearly }\end{array}$ & 3.9900 & 4 & 4.23 & 10 \\
\hline $\begin{array}{l}\text { 5. Well-organized Medical Library home } \\
\text { page }\end{array}$ & 3.89 & 5 & 4.13 & 16 \\
\hline 6. Well-organized HKUL home page & 3.87 & 6 & 4.18 & 13 \\
\hline 7. Opening hours meet my needs & 3.85 & 7 & 4.37 & 4 \\
\hline $\begin{array}{l}\text { 8. Well-organized Education Library home } \\
\text { page }\end{array}$ & 3.804 & 8 & 4.02 & 19 \\
\hline 9. Assistance from librarians & 3.798 & 9 & 3.92 & 24 \\
\hline 10. Well-organized Law Library home page & 3.78 & 10 & 4.09 & 18 \\
\hline $\begin{array}{l}\text { 11. Electronic resources is accessible from } \\
\text { my home/office }\end{array}$ & 3.74 & 11 & 4.49 & 3 \\
\hline 12. Books in your discipline & 3.72 & 12 & 4.54 & 1 \\
\hline $\begin{array}{l}\text { 13. Well-organized Music Library home } \\
\text { page }\end{array}$ & 3.71 & 13 & 3.94 & 22 \\
\hline 14. Journals in your discipline & 3.6824 & 14 & 4.26 & 8 \\
\hline 15. Electronic databases & 3.6815 & 15 & 4.23 & 11 \\
\hline $\begin{array}{l}\text { 16. Well-organized Fung Ping Shan } \\
\text { Library home page }\end{array}$ & 3.68 & 16 & 4.21 & 12 \\
\hline 17. Ease of use & 3.67 & 17 & 4.36 & 5 \\
\hline 18. Ease of locating electronic resources & 3.657 & 18 & 4.34 & 6 \\
\hline 19. Extensiveness of databases & 3.656 & 19 & 4.29 & 7 \\
\hline $\begin{array}{l}\text { 20. Being alerted to new electronic } \\
\text { resources by bulk e-mail, Focus (HKUL } \\
\text { newsletter), etc. }\end{array}$ & 3.65 & 20 & 3.43 & 27 \\
\hline $\begin{array}{l}\text { 21. Interlibrary loans (ILL) requests are } \\
\text { followed through }\end{array}$ & 3.64 & 21 & 3.94 & 23 \\
\hline 22. Books \& journals are reshelved quickly & 3.62 & 22 & 4.15 & 14 \\
\hline $\begin{array}{l}\text { 23. Library user education (courses/ } \\
\text { workshops/orientation) }\end{array}$ & 3.59 & 23 & 3.34 & 30 \\
\hline $\begin{array}{l}\text { 24. Well-organized Dental Library home } \\
\text { page }\end{array}$ & 3.574 & 24 & 3.76 & 25 \\
\hline $\begin{array}{l}\text { 25. Library orientation/ courses/ } \\
\text { workshops meet my needs }\end{array}$ & 3.571 & 25 & 3.40 & 29 \\
\hline
\end{tabular}




\begin{tabular}{|c|c|c|c|c|}
\hline \multicolumn{5}{|c|}{$\begin{array}{c}\text { TABLE } 4 \\
\text { Ranked Performance versus Importance }\end{array}$} \\
\hline Question & $\begin{array}{c}\text { Mean } \\
\text { Performance }\end{array}$ & $\underset{P}{\operatorname{Rank}}$ & $\begin{array}{c}\text { Mean } \\
\text { Importance }\end{array}$ & $\underset{\text { I }}{\text { Rank }}$ \\
\hline 26. Library printed/online guides & 3.49 & 26 & 3.54 & 26 \\
\hline $\begin{array}{l}\text { 27. Recommended materials are purchased } \\
\text { and processed rapidly for inclusion in the } \\
\text { collection }\end{array}$ & 3.46 & 27 & 4.11 & 17 \\
\hline 28. Audiovisual materials & 3.37 & 28 & 3.42 & 28 \\
\hline 29. Scores & 3.33 & 29 & 3.95 & 21 \\
\hline $\begin{array}{l}\text { 30. Prompt action is taken regarding } \\
\text { missing books \& journals }\end{array}$ & 3.31 & 30 & 3.96 & 20 \\
\hline
\end{tabular}

portance of the service or collection to the respondents and the libraries' performance as perceived by respondents. These bivariate data analyses assess the association between two variables at a time.

As seen in table 6, the three areas with the more significant gaps between user expectations and service quality for the thirty attributes are (1) books in your discipline (gap score of 0.84 , with an importance ranking of 1/30), (2) electronic resources are accessible from my home/office (gap score of 0.76 , with importance ranking of 3/30), and (3) ease of use of electronic resources (gap score of 0.71 , with an importance ranking of $5 / 30$ ). Remedial action is needed in these areas to increase user satisfaction.

The three areas with the smallest gaps between user expectations and service quality for the thirty attributes are (1) library user education (gap score of -0.22 , with an importance ranking of 30/30), (2) being alerted to new electronic resources by bulk e-mail, Focus (HKU Libraries newsletter), etc. (gap score of -0.21 , with an importance ranking of 27/30), and (3) library orientation/courses/workshops meet my needs (gap score of -0.16 , with an importance ranking of 29/30).

Ranked performance versus importance, ranked importance versus perform- ance, and ranked gap analysis data were compiled and tabulated for each of the six branch libraries and nine patron types, similar to the composite results, to compare their similarities and differences.

Composite Preference for Print versus Electronic Resources

Results demonstrated that an overwhelming 68.8 percent of the respondents prefer to use journals online compared to 31.2 percent who prefer to use print; and 71.8 percent prefer to use printed books compared to 28.2 percent who prefer using electronic books. (See figure 2.)

\section{Preference for Print versus Electronic Re- sources by Patron Type}

Preference for online journals by patron type varies from a high of 79.5 percent for others, 79.0 percent for postgraduates, and 78.6 percent for academic staff to a low of 63.4 percent for HKU SPACE students, 63.6 percent for Circle of Friends members, and 65.1 percent for undergraduates.

Preference for online books by patron type varies from a high of 41.0 percent for others, 35.5 percent for alumni, and 32.8 percent for HKU SPACE staff to a low of 20.9 percent for nonacademic staff, 22.1 percent for academic staff, and 25.5 percent for undergraduates. (See table 7.) 


\begin{tabular}{|c|c|c|c|c|}
\hline \multicolumn{5}{|c|}{$\begin{array}{c}\text { TABLE } 5 \\
\text { Ranked Important versus Performance }\end{array}$} \\
\hline Question & $\begin{array}{c}\text { Mean } \\
\text { Importance }\end{array}$ & $\begin{array}{c}\text { Rank } \\
\text { I }\end{array}$ & $\begin{array}{c}\text { Mean } \\
\text { Performance }\end{array}$ & $\begin{array}{c}\text { Rank } \\
P\end{array}$ \\
\hline 1. Books in your discipline & 4.55 & 1 & 3.72 & 12 \\
\hline $\begin{array}{l}\text { 2. Dragon, HKUL catalogue, provides } \\
\text { clear and useful information }\end{array}$ & 4.54 & 2 & 3.99 & 3 \\
\hline $\begin{array}{l}\text { 3. Electronic resources is accessible from } \\
\text { my home/office }\end{array}$ & 4.49 & 3 & 3.74 & 11 \\
\hline 4. Opening hours meet my needs & 4.37 & 4 & 3.85 & 7 \\
\hline 5. Ease of use & 4.36 & 5 & 3.67 & 17 \\
\hline 6. Ease of locating electronic resources & 4.34 & 6 & 3.657 & 18 \\
\hline 7. Extensiveness of databases & 4.29 & 7 & 3.656 & 19 \\
\hline 8. Journals in your discipline & 4.26 & 8 & 3.68 & 14 \\
\hline $\begin{array}{l}\text { 9. Library staff are readily available to } \\
\text { provide assistance and respond in a timely } \\
\text { manner }\end{array}$ & 4.24 & 9 & 4.04 & 2 \\
\hline $\begin{array}{l}\text { 10. Library staff are knowledgeable and } \\
\text { answer inquiries accurately and clearly }\end{array}$ & 4.234 & 10 & 3.99 & 4 \\
\hline 11. Electronic databases & 4.225 & 11 & 3.69 & 15 \\
\hline $\begin{array}{l}\text { 12. Well-organized Fung Ping Shan } \\
\text { Library home page }\end{array}$ & 4.21 & 12 & 3.68 & 16 \\
\hline 13. Well-organized HKUL home page & 4.18 & 13 & 3.87 & 6 \\
\hline $\begin{array}{l}\text { 14. Books \& journals are reshelved } \\
\text { quickly }\end{array}$ & 4.15 & 14 & 3.62 & 22 \\
\hline 15. Library staff are polite and friendly & 4.14 & 15 & 4.06 & 1 \\
\hline $\begin{array}{l}\text { 16. Well-organized Medical Library home } \\
\text { page }\end{array}$ & 4.13 & 16 & 3.89 & 5 \\
\hline $\begin{array}{l}\text { 17. Recommended materials are } \\
\text { purchased and processed rapidly for } \\
\text { inclusion in the collection }\end{array}$ & 4.11 & 17 & 3.46 & 27 \\
\hline $\begin{array}{l}\text { 18. Well-organized Law Library home } \\
\text { page }\end{array}$ & 4.09 & 18 & 3.78 & 10 \\
\hline $\begin{array}{l}\text { 19. Well-organized Education Library } \\
\text { home page }\end{array}$ & 4.02 & 19 & 3.80 & 8 \\
\hline $\begin{array}{l}\text { 20. Prompt action is taken regarding } \\
\text { missing books \& journals }\end{array}$ & 3.96 & 20 & 3.31 & 30 \\
\hline 21. Scores & 3.95 & 21 & 3.33 & 29 \\
\hline $\begin{array}{l}\text { 22. Well-organized Music Library home } \\
\text { page }\end{array}$ & 3.9386 & 22 & 3.71 & 13 \\
\hline $\begin{array}{l}\text { 23. Interlibrary loans (ILL) requests are } \\
\text { followed through }\end{array}$ & 3.9382 & 23 & 3.64 & 21 \\
\hline 24. Assistance from librarians & 3.92 & 24 & 3.80 & 9 \\
\hline
\end{tabular}




\begin{tabular}{|l|c|c|c|c|}
\hline \multicolumn{5}{|c|}{ TABLE 5 } \\
\hline \hline Question & $\begin{array}{c}\text { Mean } \\
\text { Importance }\end{array}$ & $\begin{array}{c}\text { Rank } \\
\text { I }\end{array}$ & $\begin{array}{c}\text { Mean } \\
\text { Performance }\end{array}$ & $\begin{array}{c}\text { Rank } \\
\text { P }\end{array}$ \\
\hline $\begin{array}{l}\text { 25. Well-organized Dental Library home } \\
\text { page }\end{array}$ & 3.76 & 25 & 3.57 & 24 \\
\hline 26. Library printed/online guides & 3.54 & 26 & 3.49 & 26 \\
\hline $\begin{array}{l}\text { 27. Being alerted to new electronic } \\
\text { resources by bulk e-mail, Focus (HKUL } \\
\text { newsletter), etc. }\end{array}$ & 3.43 & 27 & 3.65 & 20 \\
\hline 28. Audiovisual materials & 3.42 & 28 & 3.37 & 28 \\
\hline $\begin{array}{l}\text { 29. Library orientation/ courses/ } \\
\text { workshops meet my needs }\end{array}$ & 3.40 & 29 & 3.57 & 25 \\
\hline $\begin{array}{l}\text { 30. Library user education (courses/ } \\
\text { workshops/orientation) }\end{array}$ & 3.34 & 30 & 3.59 & 23 \\
\hline
\end{tabular}

Figure 3 provides a breakdown by number of these preferences by patron type.

\section{Preference for Print versus Electronic Resources by Library}

There is quite a wide difference in the preference for online journals between users of different libraries. Of the users of the Medical Library, 79.8 percent prefer accessing journals online, compared to 55.6 percent of users of the Music Library.

There also is quite a difference in the preference for online books between users of different libraries. Of the users of the Education Library, 33.8 percent prefer accessing books online, compared to 17.1 percent of the users of the Fung Ping Shan Library, which houses the Chinese, Japanese, and Korean collection. Table 8 shows the breakdown of the figures by library.

\section{Frequency in the Usage of Print and Elec- tronic Resources}

The top ten resources consulted on a daily basis include: the HKU Libraries home page; Dragon, the HKU Libraries catalogue; printed books; databases (full-text abstracts and indexes); e-journals; printed journals; e-news; e-books; the Medical
Library home page; and the Law Library home page.

The top ten resources respondents never consulted include: e-news; audiovisual materials; HKU Libraries digital initiatives (e.g., HKU Thesis Online); e-books; e-journals; printed journals; databases (full-text abstracts and indexes); newspaper clippings at the Education Library; printed books; and examination papers and syllabi at the Education Library.

Six resources appear in both the most frequently and least used lists: e-news; e-journals; printed journals; e-books; databases; and printed books. This is because some respondents never use these resources and others use them frequently. When the frequency counts are added together, these resources appear in both lists, as preferences in the use of resources vary widely and are not mutually exclusive. (See table 9.)

\section{Written Comments}

Room was provided at the end of each section and at the end of the whole survey for additional comments and suggestions to encourage open-ended responses. Eighty-eight pages of written comments were received for the main library and 


\begin{tabular}{|c|c|c|c|c|c|c|}
\hline \multicolumn{7}{|c|}{$\begin{array}{c}\text { TABLE } 6 \\
\text { Ranked Gap Scores }\end{array}$} \\
\hline Question & $\begin{array}{c}\text { Mean } \\
\text { Importance }\end{array}$ & $\underset{\text { I }}{\text { Rank }}$ & $\begin{array}{c}\text { Mean } \\
\text { Performance }\end{array}$ & $\underset{P}{\operatorname{Rank}}$ & $\begin{array}{l}\text { Mean } \\
\text { Gap }\end{array}$ & $\begin{array}{c}\text { Rank } \\
\text { G }\end{array}$ \\
\hline $\begin{array}{l}\text { 1. Books in your } \\
\text { discipline }\end{array}$ & 4.55 & 1 & 3.72 & 12 & 0.84 & 1 \\
\hline $\begin{array}{l}\text { 2. Electronic resources } \\
\text { is accessible from my } \\
\text { home/office }\end{array}$ & 4.49 & 3 & 3.74 & 11 & 0.76 & 2 \\
\hline 3. Ease of use & 4.36 & 5 & 3.67 & 17 & 0.710 & 3 \\
\hline $\begin{array}{l}\text { 4. Ease of locating } \\
\text { electronic resources }\end{array}$ & 4.34 & 6 & 3.66 & 18 & 0.706 & 4 \\
\hline $\begin{array}{l}\text { 5. Prompt action is taken } \\
\text { regarding missing books } \\
\& \text { journals }\end{array}$ & 3.96 & 20 & 3.31 & 30 & 0.673 & 5 \\
\hline $\begin{array}{l}\text { 6. Recommended } \\
\text { materials are purchased } \\
\text { and processed rapidly for } \\
\text { inclusion in the collection }\end{array}$ & 4.11 & 17 & 3.46 & 27 & 0.667 & 6 \\
\hline $\begin{array}{l}\text { 7. Extensiveness of } \\
\text { databases }\end{array}$ & 4.29 & 7 & 3.66 & 19 & 0.66 & 7 \\
\hline 8. Scores & 3.95 & 21 & 3.33 & 29 & 0.63 & 8 \\
\hline $\begin{array}{l}\text { 9. Journals in your } \\
\text { discipline }\end{array}$ & 4.26 & 8 & 3.68 & 14 & 0.59 & 9 \\
\hline $\begin{array}{l}\text { 10. Dragon, HKUL } \\
\text { catalogue provides clear } \\
\text { and useful information }\end{array}$ & 4.54 & 2 & 3.99 & 3 & 0.56 & 10 \\
\hline 11. Electronic databases & 4.23 & 11 & 3.68 & 15 & 0.551 & 11 \\
\hline $\begin{array}{l}\text { 12. Books \& journals are } \\
\text { reshelved quickly }\end{array}$ & 4.15 & 14 & 3.62 & 22 & 0.546 & 12 \\
\hline $\begin{array}{l}\text { 13. Well-organized Fung } \\
\text { Ping Shan Library home } \\
\text { page }\end{array}$ & 4.21 & 12 & 3.68 & 16 & 0.54 & 13 \\
\hline $\begin{array}{l}\text { 14. Opening hours meet } \\
\text { my needs }\end{array}$ & 4.37 & 4 & 3.85 & 7 & 0.53 & 14 \\
\hline $\begin{array}{l}\text { 15. Well-organized Law } \\
\text { Library home page }\end{array}$ & 4.09 & 18 & 3.78 & 10 & 0.33 & 15 \\
\hline $\begin{array}{l}\text { 16. Interlibrary loans } \\
\text { (ILL) requests are } \\
\text { followed through }\end{array}$ & 3.94 & 23 & 3.64 & 21 & 0.324 & 16 \\
\hline $\begin{array}{l}\text { 17. Well-organized } \\
\text { HKUL home page }\end{array}$ & 4.18 & 13 & 3.87 & 6 & 0.319 & 17 \\
\hline $\begin{array}{l}\text { 18. Library staff are } \\
\text { knowledgeable and } \\
\text { answer inquiries } \\
\text { accurately and clearly }\end{array}$ & 4.23 & 10 & 3.99 & 4 & 0.253 & 18 \\
\hline
\end{tabular}




\begin{tabular}{|c|c|c|c|c|c|c|}
\hline \multicolumn{7}{|c|}{$\begin{array}{c}\text { TABLE } 6 \\
\text { Ranked Gap Scores }\end{array}$} \\
\hline Question & $\begin{array}{c}\text { Mean } \\
\text { Importance }\end{array}$ & $\underset{\text { I }}{\text { Rank }}$ & $\begin{array}{c}\text { Mean } \\
\text { Performance }\end{array}$ & $\underset{\mathbf{P}}{\operatorname{Rank}}$ & $\begin{array}{l}\text { Mean } \\
\text { Gap }\end{array}$ & $\begin{array}{c}\text { Rank } \\
\text { G }\end{array}$ \\
\hline $\begin{array}{l}\text { 19. Well-organized } \\
\text { Music Library home } \\
\text { page }\end{array}$ & 3.94 & 22 & 3.71 & 13 & 0.25 & 19 \\
\hline $\begin{array}{l}\text { 20. Well-organized } \\
\text { Medical Library home } \\
\text { page }\end{array}$ & 4.13 & 16 & 3.89 & 5 & 0.24 & 20 \\
\hline $\begin{array}{l}\text { 21. Well-organized } \\
\text { Education Library home } \\
\text { page }\end{array}$ & 4.02 & 19 & 3.80 & 8 & 0.23 & 21 \\
\hline $\begin{array}{l}22 . \text { Library staff are } \\
\text { readily available to } \\
\text { provide assistance and } \\
\text { respond in a timely } \\
\text { manner }\end{array}$ & 4.24 & 9 & 4.04 & 2 & 0.209 & 22 \\
\hline $\begin{array}{l}\text { 23. Well-organized } \\
\text { Dental Library home } \\
\text { page }\end{array}$ & 3.76 & 25 & 3.57 & 24 & 0.206 & 23 \\
\hline $\begin{array}{l}\text { 24. Assistance from } \\
\text { librarians }\end{array}$ & 3.92 & 24 & 3.80 & 9 & 0.13 & 24 \\
\hline $\begin{array}{l}\text { 25. Library staff are } \\
\text { polite and friendly }\end{array}$ & 4.14 & 15 & 4.06 & 1 & 0.084 & 25 \\
\hline $\begin{array}{l}\text { 26. Audiovisual } \\
\text { materials }\end{array}$ & 3.42 & 28 & 3.37 & 28 & 0.075 & 26 \\
\hline $\begin{array}{l}\text { 27. Library printed/ } \\
\text { online guides }\end{array}$ & 3.54 & 26 & 3.49 & 26 & 0.073 & 27 \\
\hline $\begin{array}{l}\text { 28. Library orientation/ } \\
\text { courses/workshops meet } \\
\text { my needs }\end{array}$ & 3.40 & 29 & 3.57 & 25 & -0.16 & 28 \\
\hline $\begin{array}{l}29 \text {. Being alerted to new } \\
\text { electronic resources } \\
\text { by bulk e-mail, Focus } \\
\text { (HKUL newsletter), etc. }\end{array}$ & 3.43 & 27 & 3.65 & 20 & -0.21 & 29 \\
\hline $\begin{array}{l}\text { 30. Library user } \\
\text { education (courses/ } \\
\text { workshops/orientation) }\end{array}$ & 3.34 & 30 & 3.58 & 23 & -0.22 & 30 \\
\hline
\end{tabular}

branch libraries, covering a wide range of issues. Substantial efforts were devoted to classifying the comments according to a classification scheme developed by the User Survey Task Force. ${ }^{30}$ To maintain originality, no revisions were made to the spelling and grammar of the written comments submitted. When a comment touches on several issues, it is segregated and consolidated with the respective categories. When a comment is on another library or department, it also appears on 


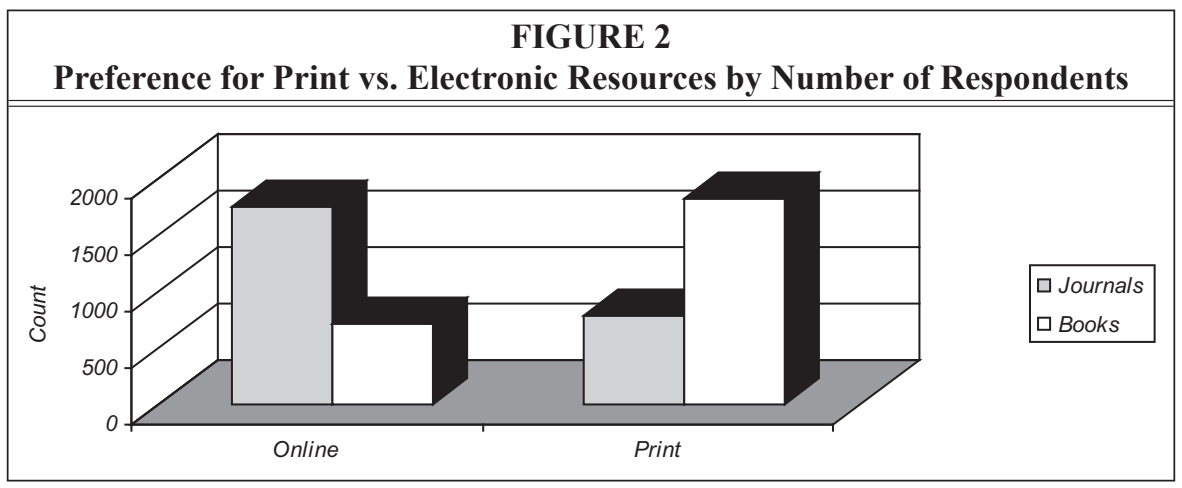

the summary of written comments of the respective library/department.

The top ten most frequently occurring suggestions for improvement at the main library were:

1. extend opening hours;

2. improvement on shelving turnaround time and tracing of missing items;

3. more e-resources;

4. improvement on the attitudes of library staff

5. access to electronic resources by alumni
6. more user-friendly timetables for user education courses and availability of online courses

7. acquiring multiple copies of heavily demanded books; improvement on HKU libraries home page

8. more user-friendly e-resources interface

9. expand the depth of the collection 10. availability of interbranch loans and improvement on circulation counter efficiency; noise from mobile phones.

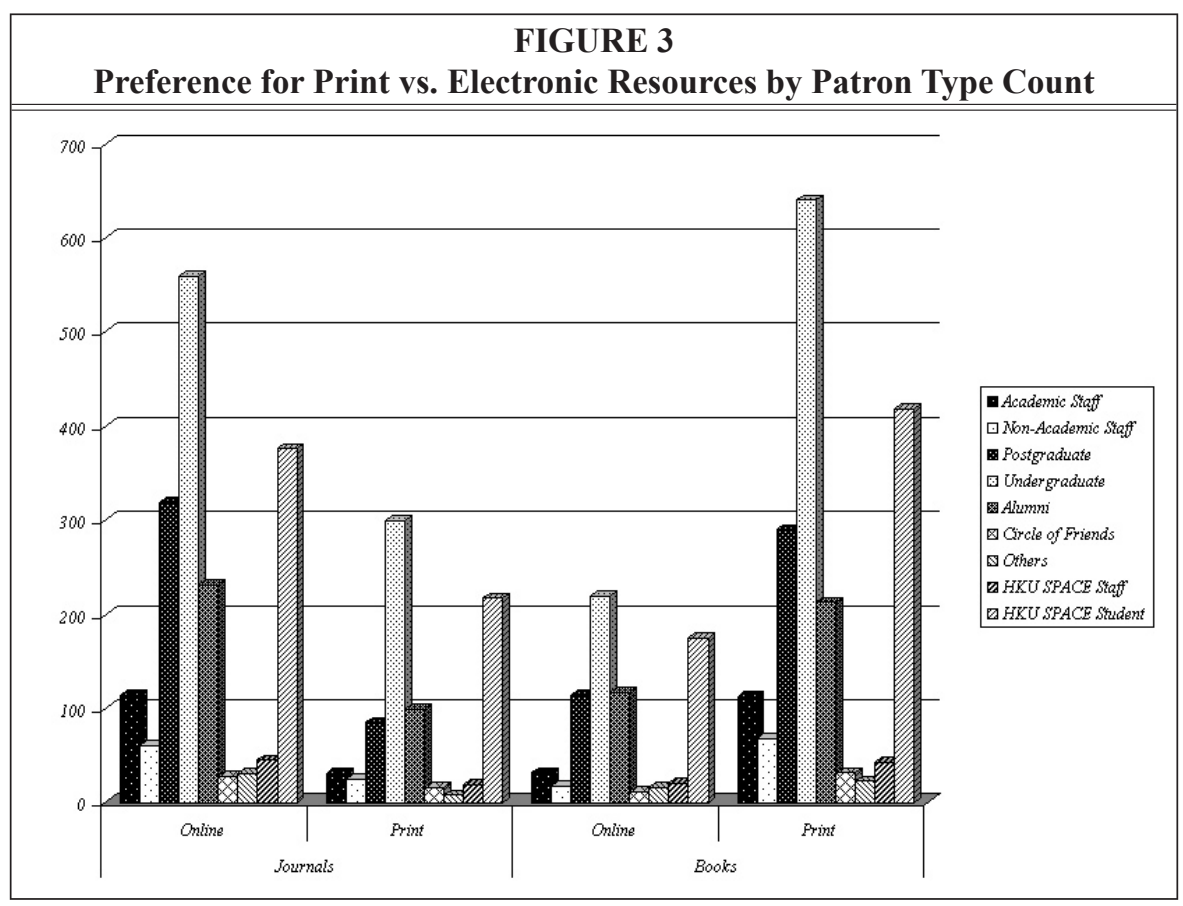


The 2004 User Survey at the University of Hong Kong Libraries 131

\begin{tabular}{|c|c|c|c|c|c|c|c|c|c|c|c|c|c|c|c|c|c|c|c|}
\hline & 节 & $\begin{array}{l}\mathbb{J} \\
\stackrel{-}{=}\end{array}$ & $\begin{array}{l}\stackrel{\circ}{0} \\
\dot{8} \\
0\end{array}$ & $\mid \begin{array}{l}00 \\
\infty \\
0 \\
0 \\
0\end{array}$ & $\stackrel{\infty}{\circ}$ & $\begin{array}{l}\stackrel{0}{\circ} \\
\dot{8} \\
\dot{0}\end{array}$ & ণें & $\begin{array}{l} \pm \\
n \\
n \\
v\end{array}$ & $\begin{array}{l}80 \\
8 \\
8 \\
8\end{array}$ & $\begin{array}{l}80 \\
\dot{8} \\
8\end{array}$ & $\underset{\mathbb{N}}{\stackrel{\Xi}{ }}$ & $\left|\begin{array}{l}\dot{0} \\
\dot{8} \\
\dot{8}\end{array}\right|$ & $\begin{array}{l}\stackrel{0}{0} \\
\text { ì } \\
\stackrel{1}{\sim}\end{array}$ & 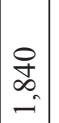 & $\begin{array}{l}00 \\
8 \\
\dot{8} \\
0\end{array}$ & $\begin{array}{l}\stackrel{0}{\infty} \\
\stackrel{-}{-}\end{array}$ & $\begin{array}{l}\mathbb{b} \\
\stackrel{2}{2} \\
\text { v }\end{array}$ & $\begin{array}{l}80 \\
\dot{8} \\
\dot{8}\end{array}$ & $\begin{array}{l}\text { ठें } \\
\dot{8}\end{array}$ \\
\hline & 苞 & हn & $\frac{\stackrel{0}{i}}{\dot{m}}$ & $\frac{0}{0}$ & ৪্ & i̊n & 吕 & $\stackrel{\curvearrowright}{\curvearrowleft}$ & $\begin{array}{l}\text { din } \\
m \\
m\end{array}$ & $\begin{array}{l}\stackrel{0}{0} \\
\dot{8} \\
\dot{0}\end{array}$ & $\frac{\curvearrowright}{\sim}$ & 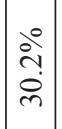 & $\begin{array}{l}0 \\
i \\
i n \\
i n \\
i\end{array}$ & $\stackrel{\circ}{+}$ & $\begin{array}{l}00 \\
\infty \\
\dot{m} \\
\dot{m}\end{array}$ & $\begin{array}{l}\stackrel{0}{i n} \\
\stackrel{+}{\sim}\end{array}$ & $\stackrel{\infty}{\infty}$ & $\begin{array}{l}\text { ì } \\
\text { mे } \\
m\end{array}$ & $\begin{array}{l}0 \\
\dot{8} \\
\dot{8}\end{array}$ \\
\hline 馬 & 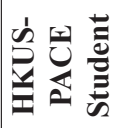 & $\frac{0}{n}$ & $\stackrel{\stackrel{\circ}{n}}{\stackrel{\sim}{\sim}}$ & $\left|\begin{array}{c}0 \\
\dot{0} \\
\dot{\sigma} \\
\hat{\sigma}\end{array}\right|$ & $\overline{\vec{\lambda}}$ & $\frac{\partial}{\stackrel{\circ}{\Delta}}$ & $\left|\begin{array}{l}00 \\
0 \\
0 \\
\dot{0} \\
n\end{array}\right|$ & ñ & $\frac{\partial^{\circ}}{\stackrel{\vec{\lambda}}{n}}$ & $\begin{array}{l}\stackrel{0}{0} \\
\dot{8} \\
\dot{0}\end{array}$ & $\cong$ & $\begin{array}{l}\stackrel{0}{\grave{j}} \\
\stackrel{+}{ }\end{array}$ & $\begin{array}{l}0 \\
i \\
i \\
\grave{n}\end{array}$ & $\frac{\infty}{\sigma}$ & 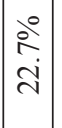 & 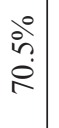 & ñ & $\frac{\partial}{\ddot{n}}$ & $\begin{array}{l}\text { Oें } \\
\dot{8} \\
\dot{0}\end{array}$ \\
\hline 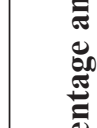 & 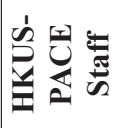 & fr & $\begin{array}{l}\stackrel{0}{b} \\
\dot{b} \\
\text { i }\end{array}$ & 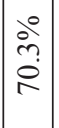 & 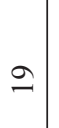 & 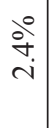 & $\begin{array}{l}\stackrel{0}{i} \\
\stackrel{2}{2}\end{array}$ & రి & $\begin{array}{l}\text { in } \\
\text { in }\end{array}$ & $\begin{array}{l}\stackrel{0}{0} \\
\dot{8} \\
\dot{0}\end{array}$ & $\vec{\sim}$ & 亏ें & $\begin{array}{l}\stackrel{0}{0} \\
\infty \\
\dot{c} \\
\text { mे }\end{array}$ & $\stackrel{\mathscr{f}}{\forall}$ & ì & $\frac{0}{i}$ & రి & $\begin{array}{c}\circ \\
i n \\
i\end{array}$ & $\begin{array}{l}\stackrel{0}{0} \\
\dot{8}\end{array}$ \\
\hline $\begin{array}{l}0 \\
0 \\
0 \\
0 \\
0\end{array}$ & 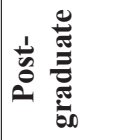 & $\frac{\curvearrowright}{m}$ & $\frac{0^{0}}{-\infty}$ & $\mid \begin{array}{l}00 \\
\vdots \\
0 \\
2\end{array}$ & $\infty$ & $\begin{array}{l}\stackrel{0}{0} \\
\stackrel{0}{0} \\
0\end{array}$ & 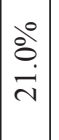 & ষ্ণ & $\begin{array}{l}0 \\
\infty \\
0 \\
-1\end{array}$ & $\begin{array}{l}\stackrel{0}{0} \\
\dot{8} \\
\dot{8}\end{array}$ & $\Xi$ & 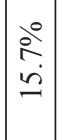 & $\begin{array}{l}\stackrel{0}{0} \\
\stackrel{1}{\infty} \\
\infty \\
\sim\end{array}$ & ৯ิ & $\left|\begin{array}{l}0 \\
\infty \\
0 \\
-1\end{array}\right|$ & $\begin{array}{l}\stackrel{0}{\infty} \\
\stackrel{\infty}{\nabla}\end{array}$ & $\underset{f}{\stackrel{+}{*}}$ & 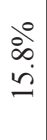 & $\begin{array}{l}\stackrel{0}{0} \\
\dot{8} \\
\dot{0}\end{array}$ \\
\hline อี & 离 & $\bar{n}$ & $\begin{array}{l}\stackrel{0}{\infty} \\
\stackrel{-}{-}\end{array}$ & $\begin{array}{l}a \\
i n \\
2 \\
2\end{array}$ & $\infty$ & $\stackrel{\circ}{\circ}$ & 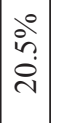 & ले & i̊ & $\begin{array}{l}\stackrel{0}{0} \\
\dot{8} \\
\dot{0}\end{array}$ & 0 & ํํㄹ & $\begin{array}{l}\stackrel{0}{0} \\
\stackrel{\dot{\gamma}}{\sigma}\end{array}$ & $\widehat{\curvearrowright}$ & 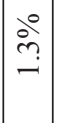 & $\begin{array}{l}\stackrel{0}{0} \\
\stackrel{0}{n} \\
i\end{array}$ & ले & 咢 & 追 \\
\hline 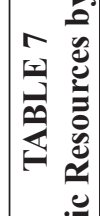 & 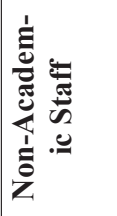 & $\overline{6}$ & 总 & 号 & $\approx$ & $\frac{\partial}{\dot{m}}$ & $\frac{\partial^{0}}{\partial \dot{a}}$ & 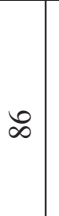 & $\begin{array}{l}\stackrel{\circ}{\circ} \\
\dot{+} \\
\dot{n}\end{array}$ & 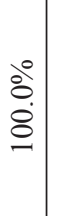 & $\stackrel{\infty}{-}$ & i̊ & 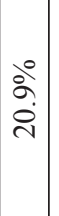 & 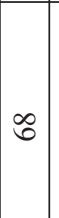 & $\frac{\grave{i}}{\dot{m}}$ & $\frac{0^{0}}{2}$ & $\infty$ & $\begin{array}{l}\stackrel{0}{+} \\
\dot{r}\end{array}$ & $\begin{array}{l}0 \\
\dot{\delta} \\
\dot{8}\end{array}$ \\
\hline $\begin{array}{l}\overline{0} \\
\frac{0}{0} \\
\underline{\theta}\end{array}$ & 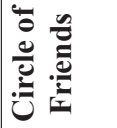 & $\stackrel{\infty}{\sim}$ & $\begin{array}{l}\text { oे } \\
\text { - }\end{array}$ & 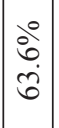 & 0 & $\begin{array}{l}\stackrel{\circ}{0} \\
\dot{i}\end{array}$ & 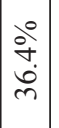 & 寸 & $\stackrel{ }{\stackrel{2}{-}}$ & $\begin{array}{l}\stackrel{0}{0} \\
\dot{8} \\
8\end{array}$ & $\simeq$ & $\stackrel{2}{\stackrel{2}{-}}$ & 官 & nె & $\stackrel{\circ}{\stackrel{2}{2}}$ & $\begin{array}{l}\stackrel{0}{i} \\
i \\
i\end{array}$ & 寸 & $\stackrel{\circ}{\stackrel{0}{\imath}}$ & $\begin{array}{l}0 \\
\dot{8} \\
\dot{8}\end{array}$ \\
\hline 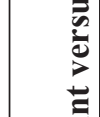 & 总 & $\overline{\widetilde{\sim}}$ & $\begin{array}{l}\stackrel{0}{\partial} \\
\ddot{2}\end{array}$ & $\mid \begin{array}{l}0 \\
\dot{0} \\
0 \\
0\end{array}$ & হ & 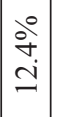 & $\begin{array}{l}\dot{0} \\
\dot{0} \\
\dot{\rho} \\
\end{array}$ & 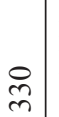 & $\begin{array}{l}\stackrel{0}{a} \\
\text { ปे }\end{array}$ & $\begin{array}{l}\stackrel{0}{0} \\
\dot{8} \\
\dot{0}\end{array}$ & $\cong$ & $\begin{array}{l}\stackrel{0}{0} \\
\underline{0}\end{array}$ & $\begin{array}{l}\text { ò } \\
i n \\
i n \\
m\end{array}$ & $\frac{m}{\sim}$ & $\begin{array}{l}\stackrel{0}{0} \\
\stackrel{i}{=}\end{array}$ & $\begin{array}{l}\stackrel{0}{i} \\
i \overrightarrow{0}\end{array}$ & 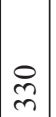 & $\begin{array}{l}\stackrel{0}{a} \\
\stackrel{\text { ja }}{ }\end{array}$ & $\begin{array}{l}0 \\
\text { Oें } \\
\dot{8}\end{array}$ \\
\hline 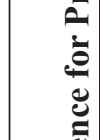 & 兽 & $\stackrel{\Xi}{\Xi}$ & iें & $\begin{array}{l}\stackrel{0}{b} \\
\stackrel{0}{\infty}\end{array}$ & $\vec{m}$ & ڤें & $\frac{\stackrel{\circ}{+}}{\stackrel{\sim}{\Delta}}$ & $\stackrel{?}{\exists}$ & $\begin{array}{l}\stackrel{\circ}{\circ} \\
\dot{n}\end{array}$ & $\begin{array}{l}\stackrel{0}{0} \\
\dot{8} \\
\dot{8}\end{array}$ & N & $\stackrel{\stackrel{\circ}{+}}{+}$ & $\frac{\partial}{\partial}$ & $\stackrel{\varrho}{=}$ & $\frac{\partial^{0}}{\sigma^{\circ}}$ & $\frac{\stackrel{\circ}{\circ}}{\hat{\alpha}}$ & $\stackrel{f}{ \pm}$ & $\begin{array}{l}\stackrel{0}{R} \\
i \\
i\end{array}$ & $\begin{array}{l}0 \\
\dot{\delta} \\
\dot{8}\end{array}$ \\
\hline 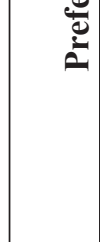 & & $\begin{array}{l}\stackrel{\Xi}{\Xi} \\
\dot{\Xi}\end{array}$ & 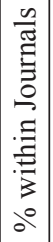 & 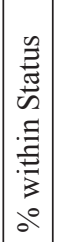 & $\begin{array}{l}\vec{\Xi} \\
\dot{\Xi} \\
\dot{U}\end{array}$ & 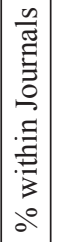 & 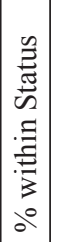 & $\stackrel{ }{\Xi}$ & 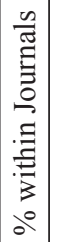 & 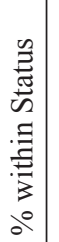 & $\vec{\Xi}$ & \begin{tabular}{|c|}
0 \\
0 \\
0 \\
0 \\
0 \\
.$\Xi$ \\
$\vdots$ \\
0 \\
3 \\
0 \\
0
\end{tabular} & 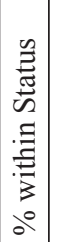 & 志 & $\mid$\begin{tabular}{c|}
$n$ \\
0 \\
0 \\
0 \\
0 \\
.$\Xi$ \\
$\vdots$ \\
$\vdots$ \\
0 \\
0
\end{tabular} & 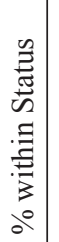 & $\vec{\Xi}$ & $\begin{array}{c}n \\
y \\
0 \\
0 \\
0 \\
. \Xi \\
\vdots \\
\vdots \\
0 \\
0 \\
0\end{array}$ & 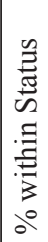 \\
\hline & & & & & & & & $\stackrel{\bar{\pi}}{0}$ & & & 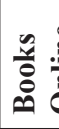 & 洰 & & 然 & & & $\overline{\mathrm{I}}$ & & \\
\hline
\end{tabular}




\section{Library Response to the Survey}

The results of the user survey were communicated internally to all members of the Senior Management Team, the Quality Assurance Team, the department heads, and the branch librarians. Each department head of the main library and each branch librarian prepared an action plan to address the ten most common areas targeted for improvement. Action plans then were communicated externally to users via plasma televisions in library entrances, bulletin boards, and Staff Student Consultative Committee meetings. A message from the University Librarian also was published in the libraries' newsletter. ${ }^{31}$ The user survey report together with the action plans from the main library and the branch libraries also were posted on HKU Libraries' home page.

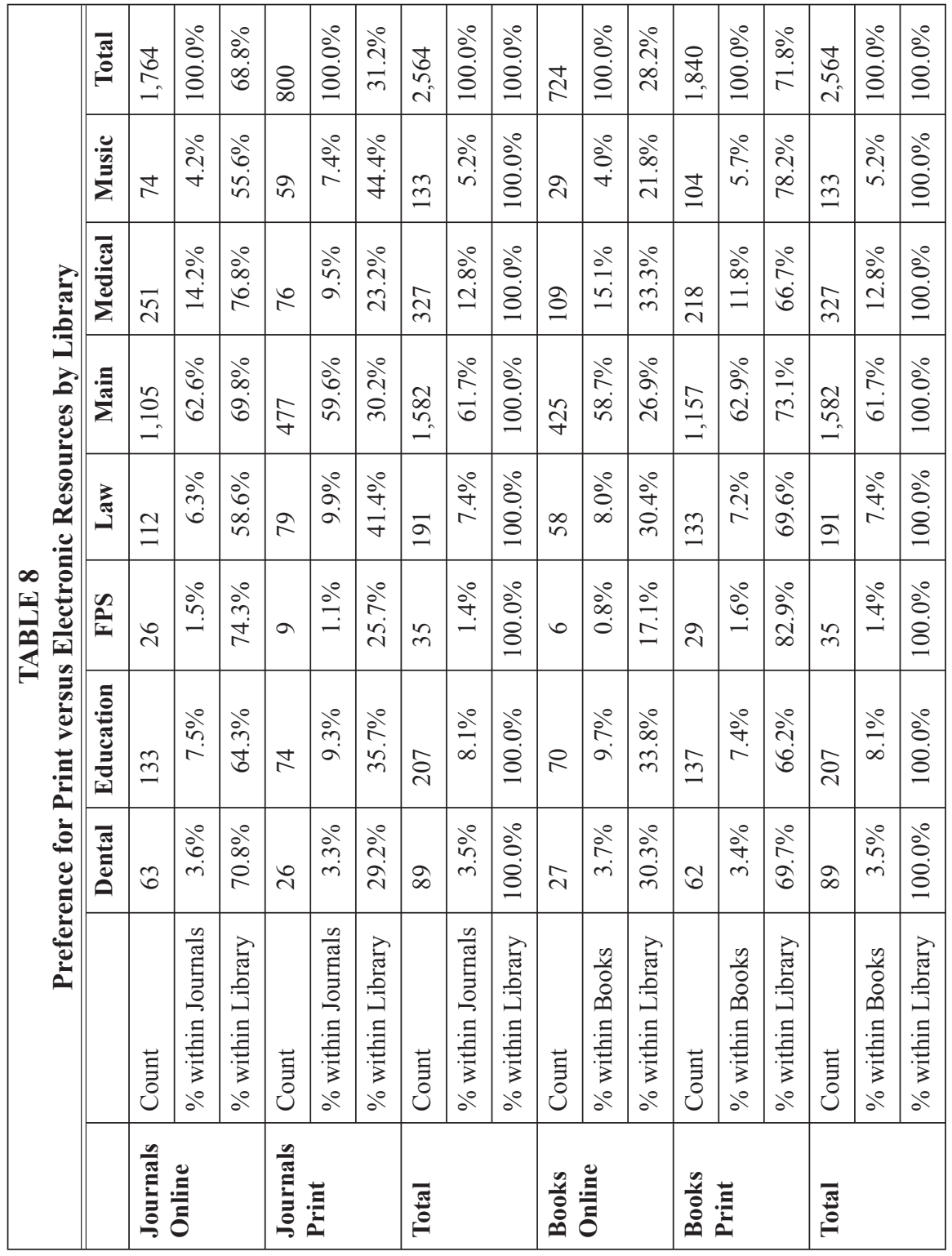




\begin{tabular}{|c|c|c|c|c|c|c|c|}
\hline \multicolumn{8}{|c|}{$\begin{array}{c}\text { TABLE } 9 \\
\text { Frequency in the Usage of Print and }\end{array}$} \\
\hline Frequency & $\begin{array}{c}\text { No } \\
\text { Input }\end{array}$ & Daily & Weekly & Monthly & $\begin{array}{l}\text { A Few } \\
\text { Times }\end{array}$ & Never & Total \\
\hline 1. Printed books & & 379 & 938 & 685 & 468 & 94 & 2,564 \\
\hline 2. Printed journals & & 140 & 542 & 589 & 863 & 430 & 2,564 \\
\hline 3. Audiovisual materials & 35 & 28 & 253 & 294 & 895 & 1,059 & 2,564 \\
\hline $\begin{array}{l}\text { 4. Faculty publications } \\
\text { database }\end{array}$ & 2,475 & 1 & 7 & 9 & 35 & 37 & 2,564 \\
\hline 5. Theses collection & 2,475 & 5 & 2564 & 52 & 28 & 4 & 2,564 \\
\hline $\begin{array}{l}\text { 6. Faculty of education } \\
\text { theses }\end{array}$ & 2,358 & 20 & 2564 & 95 & 80 & 11 & 2,564 \\
\hline $\begin{array}{l}\text { 7. Examination papers \& } \\
\text { syllabuses }\end{array}$ & 2,358 & 1 & 22 & 26 & 69 & 88 & 2,564 \\
\hline 8. Newspaper clippings & 2,358 & 4 & 12 & 28 & 53 & 109 & 2,564 \\
\hline $\begin{array}{l}\text { 9. Legislation law reports, } \\
\text { etc. }\end{array}$ & 2,375 & 28 & 58 & 49 & 41 & 13 & 2,564 \\
\hline 10. Scores & 2,431 & 6 & 37 & 29 & 28 & 33 & 2,564 \\
\hline 11. HKUL home page & & 822 & 1106 & 298 & 278 & 60 & 2,564 \\
\hline $\begin{array}{l}\text { 12. Dragon HKUL } \\
\text { catalogue }\end{array}$ & & 765 & 1271 & 319 & 175 & 34 & 2,564 \\
\hline $\begin{array}{l}\text { 13. Databases (full-text } \\
\text { abstracts \& indexes) }\end{array}$ & & 296 & 844 & 592 & 535 & 297 & 2,564 \\
\hline 14. E-journals & & 229 & 650 & 540 & 612 & 533 & 2,564 \\
\hline 15. E-books & & 63 & 300 & 501 & 916 & 784 & 2,564 \\
\hline 16. E-news & & 70 & 213 & 357 & 754 & 1,170 & 2,564 \\
\hline $\begin{array}{l}\text { 17. HKUL digital initiatives } \\
\text { (e.g. HKU Thesis Online, } \\
\text { ExamBase etc.) }\end{array}$ & 4 & 40 & 224 & 455 & 945 & 896 & 2,564 \\
\hline $\begin{array}{l}\text { 18. Dental Library } \\
\text { home page }\end{array}$ & 2,475 & 9 & 24 & 10 & 23 & 23 & 2,564 \\
\hline $\begin{array}{l}\text { 19. Faculty publications } \\
\text { database }\end{array}$ & 2,475 & 1 & 2 & 5 & 35 & 46 & 2,564 \\
\hline $\begin{array}{l}\text { 20. Education Library } \\
\text { home page }\end{array}$ & 2,357 & 10 & 48 & 49 & 55 & 45 & 2,564 \\
\hline $\begin{array}{l}\text { 21. Fung Ping Shan } \\
\text { Library home page }\end{array}$ & 2,529 & 4 & 11 & 5 & 5 & 10 & 2,564 \\
\hline $\begin{array}{l}\text { 22. Law Library } \\
\text { home page }\end{array}$ & 2,373 & 45 & 60 & 33 & 36 & 17 & 2,564 \\
\hline $\begin{array}{l}\text { 23. Medical Library home } \\
\text { page }\end{array}$ & 2,237 & 62 & 137 & 56 & 51 & 21 & 2,564 \\
\hline $\begin{array}{l}\text { 24. Music Library } \\
\text { home page }\end{array}$ & 2,431 & 9 & 35 & 29 & 38 & 22 & 2,564 \\
\hline
\end{tabular}




\section{Conclusion}

Online survey proved to be popular with the University of Hong Kong Libraries' users. Compared to a print survey conducted in 2001, 759 more returns were received in the online survey. In addition, many more free comments were received, conveying the message that the online mode is preferred for the upcoming survey despite the greater technical complexity in its deployment. The pilot tests were very helpful in shaping the length and content of the questionnaire, and should be included as a necessary part of the implementation process. Bulk-mail reminders through HKU's intranet also proved to be effective, as evidenced by the higher number of returns on February 10, 14, and 19 when the reminders appeared, reflecting the positive correlation between the two. Only a total of 706 souvenirs were collected (table 1 ) by 27.5 percent of the respondents. This is a good indication that material incentives might not be the main reason the user surveys were completed.
In previous surveys, library staff only measured user satisfaction and learned about their performance in the areas of services, collections, and staff. This is the first time the libraries asked respondents to rate attributes both on their importance and library staff performance via the gap analysis. Despite the fact that it takes longer to complete the survey, it conveys a better picture of how well the libraries stand. Services that are of high importance, but poor performance, should be addressed much sooner than those of low importance. According to research conducted by Rodski Behavioural Research Group, gaps larger than or equal to 2.00 are considered significant with a rating scale of 1 to $7 .{ }^{32}$ Using the same principle, the task force estimated that gap scores larger than or equal to 1.33 are considered significant with a rating scale of 1 to 5 . Therefore, the task force concluded that there is no significant gap between staff performance and user expectations in any area. As a matter of fact, the negative gap scores indicate that staff performance may be even above users' expectations.

\section{Notes}

1. Helen Woo, Music Library (chairperson); Andy Choi, Systems Department; Kim Tung, Reference Department; and Irene Fung, Collection Development Department.

2. Dave Low and Andy Lau from the Systems Department were added to the task force subsequently.

3. Adams Bodomo, Mei-ling Lam, and Carmen Lee, "Some Students Still Read Books in the 21st Century: A Study of User Preferences for Print and Electronic Libraries," Reading Matrix 3, no. 3 (2003): 34-48.

4. Marc T. Braverman, Jana Kay Slater, and American Evaluation Association, Advances in Survey Research (San Francisco: Jossey-Bass, 1996).

5. Rowena Cullen, "Perspectives on User Satisfaction Surveys," Library Trends 49, no. 4 (2001): $662-86$.

6. Arlene Fink, and Jacqueline B. Kosecoff, How to Conduct Surveys: A Step-by-Step Guide, 2nd ed. (Thousand Oaks, Calif.: Sage, 1998).

7. Salve Regina University, Mckillop Library User Survey. April 2003 [cited 17 October 2003]. Available online from http://library.salve.edu/user_survey.html.

8. Peter M. Nardi, Doing Survey Research: A Guide to Quantitative Method (Boston: Allyn and Bacon, 2003).

9. Isadore Newman and Keith A. McNeil, Conducting Survey Research in the Social Science (Lanham, Md.: Univ. Press of America, 1998).

10. George R. Plosker, "Conducting User Surveys: An Ongoing Information Imperative," Online (Sept./Oct. 2002): 64-68.

11. Louis M. Rea and Richard A. Parker, Designing and Conducting Survey Research: A Comprehensive Guide, 2nd ed. (San Francisco: Jossey-Bass, 1997).

12. University College London, Institute of Neurology, Rochester Institute of Technology 
Library, Wallace Library Users Survey 2002/2003. July 31, 2003 [cited 8 October 2003]. Available online from http://wally.rit.edu/general/usersurvey.html.

13. Rockefeller Medical Library, Rockefeller Medical Library Services Questionnaire. June 3, 2003 [cited 10 October 2003]. Available online from http://www.ion.ucl.ac.uk/library/samform.html.

14. Rodski Research Group, 2002 Library Survey Results. The University of Newcastle, Australia. July 10, 2003 [cited 11 October 2003]. Available online from http://www.newcastle.edu. au/services/library/about/rodski/2002/index.html.

15. — 2003 Library Survey Results. July 10, 2003 [cited 11 October 2003]. Available online from http://www.newcastle.edu.au/services/library/about/rodski/2003/2003-results.html.

16. Joe Ryan, Information Resources for Information Professionals: Library Surveys \& Questionnaires. 2003 [cited 10 October 2003]. Available online from http://web.syr.edu/ jryan/infopro/survey. html.

17. Samuel Freudenthal Memorial Library, Trinidad State Junior College, Library Survey Results 1998 [cited 10 October 2003]. Available online from http://www.tsjc.cccoes.edu/library/libsurveyresults.htm.

18. Matthias Schonlau, Ronald D. Fricker, and Marc N. Elliott, Conducting Research Surveys via E-mail and the Web (Santa Monica, Calif.: Rand, 2002).

19. Surveytools Corporation, Library Satisfaction Questionnaire. 2003 [cited 10 October 2003]. Available online from http://www.surveytools.com/library.htm.

20. Susan J. Thomas, Designing Surveys That Work! A Step-by-Step Guide (Thousand Oaks, Calif.: Corwin Pr., 1999).

21. UCSD Libraries User Survey Team, UCSD Libraries User Survey. San Diego: Univ. of California, 2003 [cited 10 October 2003]. Available online from http://orpheus.ucsd.edu/survey/index. html.

22. State University of New York, University at Albany Libraries, Libqual+Tm Spring 2003 Survey Institution Results. 2003 [cited 17 October 2003]. Available online from http://library.albany. edu/new/UA_LIBQUAL+.pdf.

23. University Libre de Bruxelles, University of Antwerp, Virlib Questionnaire. 2003 [cited 11 October 2003]. Available online from http://lib.ua.ac.be/VIRLIB/T03/survey_e.html.

24. With advice from Peter Sidorko, deputy librarian.

25. With assistance from Andy Lau, Systems Department.

26. In consultation with Peter Sidorko, deputy librarian.

27. With assistance from Andy Choi, Systems Department.

28. The Quality Assurance Team consists of team leaders from Technical Services, Reader Services, Branch Libraries, Collection Development, Library Administration, and the deputy librarian.

29. With assistance from Dave Low, Systems Department.

30. Anthony Ferguson and Kim Tung assisted in categorizing the fifty-five pages of written comments on the main library. Kim Tung also assisted in categorizing written comments on the Fung Ping Shan Library. Branch librarians Julia Chan (medical librarian), Irene Shieh (law librarian), Sam Lee (dental librarian), and Helen Woo (music librarian and interim education librarian) assisted in categorizing written comments on their own branch library/libraries.

31. Anthony Ferguson, "Your Views on How We Are Doing," Focus. The University of Hong Kong Libraries New Series 3, no. 4 (Mar./Apr. 2004): 3-4.

32. Rodski Behavioural Research Group, University of Newcastle Library Client Survey May 2003 (Newcastle upon Tyne, Eng.: Rodski Behavioural Research Group, 2003). 